DOE/NASA/16310-18

NASA TM-106350

\title{
Tensile and Stress-Rupture Behavior of Hafnium Carbide Dispersed Molybdenum and Tungsten Base Alloy Wires
}

Hee Man Yun

Cleveland State University

Cleveland, Ohio 44115

and

Robert $\mathrm{H}$. Titran

National Aeronautics and Space Administration

Lewis Research Center

Cleveland, Ohio 44135

Work performed for

U.S. DEPARTMENT OF ENERGY

Nuclear Energy

Reactor Systems Development and Technology

Washington, D.C. 20545

Under Interagency Agreement DE-Al03-86SF16310

Prepared for

The Materials Research Society Fall Meeting

Boston, Massachusetts, December 1-5, 1993 



\title{
TENSILE AND STRESS-RUPTURE BEHAVIOR OF HAFNIUM CARBIDE DISPERSED MOLYBDENUM AND TUNGSTEN BASE ALLOY WIRES
}

\author{
H.M. YUN* ${ }^{\dagger}$ AND R.H. TITRAN** \\ *Cleveland State University, Cleveland, Ohio 44115 \\ **National Aeronautics and Space Administration, Lewis Research Center, \\ 21000 Brookpark Road, Cleveland, Ohio 44135
}

\begin{abstract}
The tensile strain rate sensitivity and the stress-rupture strength of Mo-base and W-base alloy wires, $380 \mu \mathrm{m}$ in diameter, were determined over the temperature range from 1200 to $1600 \mathrm{~K}$. Three molybdenum alloy wires; Mo $+1.1 \mathrm{wt} \%$ hafnium carbide (MoHfC), Mo $+25 \mathrm{wt} \% \mathrm{~W}+$ $1.1 \mathrm{wt} \%$ hafnium carbide $(\mathrm{MoHfC}+25 \mathrm{~W})$ and $\mathrm{Mo}+45 \mathrm{wt} \% \mathrm{~W}+1.1 \mathrm{wt} \%$ hafnium carbide (MoHfC $+45 \mathrm{~W}$ ), and a W $+0.4 \mathrm{wt} \%$ hafnium carbide (WHfC) tungsten alloy wire were evaluated.

The tensile strength of all wires studied was found to have a positive strain rate sensitivity. The strain rate dependency increased with increasing temperature and is associated with grain broadening of the initial fibrous structures. The hafnium carbide dispersed W-base and Mo-base alloys have superior tensile and stress-rupture properties than those without HfC. On a density compensated basis the MoHfC wires exhibit superior tensile and stress-rupture strengths to the WHfC wires up to approximately $1400 \mathrm{~K}$. Addition of tungsten in the Mo-alloy wires was found to increase the long-term stress-rupture strength at temperatures above $1400 \mathrm{~K}$. Theoretical calculations indicate that the strength and ductility advantage of the HfC dispersed alloy wires is due to the resistance to recrystallization imparted by the dispersoid.
\end{abstract}

\section{INTRODUCTION}

High temperature applications such as space power conversion have generated great interest in fiber reinforced metallic composites. Refractory metals and alloys reinforced with refractory metal alloy fibers have been shown to be applicable for extremely high temperature ranges [1]. The useful temperature depends upon the combination of fiber and matrix. The tungsten $(W)$ fiber reinforced niobium alloy composite was reported to have high tensile and creep strength in the temperature range of 1400 to $1500 \mathrm{~K}$ [1]. The performance of a composite is usually dependent upon the fiber component. The major portion of the tensile and creep strength of the composite is associated with the properties of the fiber. The use of a strong and stiff fiber is desired for a high strength composite material.

Wires of the hafnium carbide dispersion strengthened $W$ and W-Re alloys, ranging in diameter from 200 to $380 \mu \mathrm{m}$, have recently been shown to possess superior tensile and stress-rupture strengths, compared to the potassium bubble dispersed or the thoria dispersed $W$ wires $[2,3]$. The fine hafnium carbide dispersoids were reported to be more effective than bubble or thoria dispersoids $[3,4]$ in preserving the heavily unidirectionally elongated fibrous grain structure of the $W$ alloy wires. The effectiveness of the hafnium carbide on the mechanical properties of other

\footnotetext{
${ }^{\dagger}$ NASA Resident Research Associate at Lewis Research Center.
} 
refractory metal base alloy wires, such as molybdenum (Mo), is of interest. Molybdenum (Mo) with its lower density than $W$ appears to be attractive for making lower weight composites.

Houck $[5,6]$ has studied the mechanical properties of Mo alloys, such as TZC (Mo $+1.25 \%$ $\mathrm{Ti}+0.30 \% \mathrm{Zr}+0.15 \% \mathrm{C}), \mathrm{TZM}(\mathrm{Mo}+0.5 \% \mathrm{Ti}+0.08 \% \mathrm{Zr}+0.015 \% \mathrm{C}), \mathrm{Mo}+0.5 \% \mathrm{Ti}$ (all percentages in this report are in weight percent) and $\mathrm{Mo}+0.5 \% \mathrm{Zr}$, and reported that the recrystallization temperature for these alloys varies from 1200 to $1700 \mathrm{~K}$, depending on the alloying element. The TZC and TZM alloys possess a relatively high tensile strength, but the alloying elements do not appear stable at the higher testing temperatures. The stress-rupture strength of these alloys generally are much lower than the W-base alloys. The present study focussed on the determination of the tensile and stress-rupture properties of the hafnium carbide dispersed Mo-based alloy wires and on the comparison with hafnium carbide dispersed W alloy wires. The study also evaluated the effect of HfC dispersoids in stabilizing the fibrous microstructures in the wires in the temperature range of 1200 to $1600 \mathrm{~K}$.

\section{EXPERIMENTAL PROCEDURE}

Materials

The chemical compositions of the hafnium carbide dispersed Mo and $W$ alloy wires examined in this study are given in Table $\mathrm{I}$. MoHfC wires, Mo with hafnium carbide, were the HfC dispersed simple Mo-base alloys, and MoHfC $+45 \mathrm{~W}$ and MoHfC $+25 \mathrm{~W}$ wires were the HfC dispersed and alloyed with $49.5 \% \mathrm{~W}$ and $30.4 \% \mathrm{~W}$, respectively. The Mo-base wires were fabricated by powder metallurgy techniques, the W-base WHfC wires were produced by vacuum arc-melting process.

Hafnium carbide in the Mo alloys was formed from alloying of elemental Hf and C during sintering at high temperature. This Mo alloy wire $(\mathrm{MoHfC}+45 \mathrm{~W})$ is believed to have about $0.1 \%$ HfC and about $0.7 \%$ HfC for WHfC. The MoHfC wires also contained a small unintended amount (4\%) of W, which can provide some solid-solution strengthening. The WHfC wires were strengthened by the $0.4 \% \mathrm{HfC}$ dispersoids without additional alloying elements.

All wires were heavily drawn to their final nominal diameter of about $380 \mu \mathrm{m}$. Figure 1 shows the microstructures of the as-drawn wires in this study. The grain structures are noted as infinitely long and of a very fine width, so-called fibrous grain structures. The grain width of the MoHfC wires is about $0.5 \mu \mathrm{m}$, and that of the WHfC wires about $0.3 \mu \mathrm{m}$. The size distribution

TABLE I.-CHEMICAL COMPOSITION OF MO AND W BASE ALLOY WIRES

\begin{tabular}{|c|c|c|c|c|c|c|}
\hline \multirow[t]{2}{*}{ Material } & \multicolumn{6}{|c|}{ Chemical composition, wt\% (at.\%) } \\
\hline & $\mathrm{C}$ & $\mathbf{N}$ & 0 & Hf & $\mathbf{W}$ & Mo \\
\hline MoHfC & $\begin{array}{c}0.044 \\
(0.36)\end{array}$ & 0.0026 & 0.016 & $\begin{array}{c}1.2 \\
(0.66)\end{array}$ & $\begin{array}{c}4.4 \\
(2.50)\end{array}$ & Balance \\
\hline $\mathrm{MoHfC}+25 \mathrm{~W}$ & $\begin{array}{c}0.020 \\
(0.19)\end{array}$ & 0.0023 & 0.0036 & $\begin{array}{c}0.9 \\
(0.56)\end{array}$ & $\begin{array}{c}30.4 \\
(19.0)\end{array}$ & Balance \\
\hline MoHfC $+45 \mathrm{~W}$ & $\begin{array}{l}0.0096 \\
(0.10)\end{array}$ & 0.0019 & 0.0038 & $\begin{array}{c}0.8 \\
(0.56)\end{array}$ & \begin{tabular}{|c|}
49.5 \\
$(34.8)$ \\
\end{tabular} & Balance \\
\hline WHfC & $\left(\begin{array}{l}0.03 \\
0.45)\end{array}\right.$ & 0.0009 & 0.0039 & $\begin{array}{c}0.4 \\
(0.41)\end{array}$ & Balance & - \\
\hline
\end{tabular}


of the dispersoids in the MoHfC wires was inhomogeneous, ranging from less than 0.1 to $1.0 \mu \mathrm{m}$, whereas dispersoids in the WHfC wires were finely distributed with an average size of less than about $0.1 \mu \mathrm{m}$. MoHfC $+25 \mathrm{~W}$ and $\mathrm{MoHfC}+45 \mathrm{~W}$ wires appear to result in a finer grain width and a more inhomogeneous spacing of the dispersoids than the MoHfC wires.

\section{$\underline{\text { Test Procedure }}$}

Tensile and stress-rupture tests were conducted in a vacuum of $10^{-5} \mathrm{~Pa}$ at temperatures ranging from 1200 to $1600 \mathrm{~K}$. Furnace test temperature was monitored with a platinum/platinum-13\% rhodium thermocouple, and controlled within $\pm 3 \mathrm{~K}$ during the test. The experimental details of the tensile and stress-rupture test procedures have been given previously $[3,7]$. The wire was cut to about $40 \mathrm{~cm}$ lengths and then suspended through a vertically mounted resistance furnace. Tensile testing was at a constant cross-head speed and the load-time curves were recorded autographically. The proportional limit (PL), ultimate tensile strength (UTS) were determined from the load-time curves. For the stress-rupture test, the wire was loaded with an appropriate deadweight, which was supported by a retractable support during specimen heating. The stress-rupture strength $\left(\sigma_{\mathrm{t}}\right)$ was determined from the stress versus rupture time plots. The reduction of area (RA) of failed specimens was measured using an optical split image microscope at 150 magnification.

Stress-rupture and tensile tests were performed on wires in the as-drawn condition. In addition tensile tests were performed on specimens electropolished [3] to produce a definite gauge section about $25.4 \mathrm{~mm}$ long and $280 \pm 10 \mu \mathrm{m}$ in diameter.

\section{RESULTS}

\section{Tensile Stress-Strain Rate Behavior}

The effect of the strain rates at 1400 and $1600 \mathrm{~K}$ on the PL of the as-drawn and electropolished wires is shown in Fig. 2. The electropolishing provided a tensile specimen with a well defined $25.4 \mathrm{~mm}$ long gauge section. The PL of the electropolished wires appeared to be higher than that of the as-drawn wires, about 650 and $480 \mathrm{MPa}$ at $1400 \mathrm{~K}$. The original $380 \mu \mathrm{m}$ wire diameter was reduced to $280 \mu \mathrm{m}$. The strain rates were calculated based on the assumption that all deformation took place in the electropolished gauge section.

The decrease of the PL with decreasing strain rate was small or negligible at the high strain rate range of $3.3 \times 10^{-4}$ to $3.3 \times 10^{-2} \mathrm{sec}^{-1}$. However, it is noted that the drop of the PLs is quite large at the slower strain rates, $3.3 \times 10^{-4}$ to $3.3 \times 10^{-5} \mathrm{sec}^{-1}$. The drop of the PLs at the low strain rates is due to the onset of primary recrystallization at 1400 to $1600 \mathrm{~K}$. The difference in the dependency of the strain rate between the MoHfC, MoHfC $+25 \mathrm{~W}$ and MoHfC $+45 \mathrm{~W}$ wires was negligible at $1400 \mathrm{~K}$. At $1600 \mathrm{~K}$ the PL of $\mathrm{MoHfC}+45 \mathrm{~W}$ wires is higher than that of the MoHfC wires over the strain rate range studied.

\section{Stress-Rupture Properties}

The stress-rupture properties of the as-drawn wires are shown in Fig. 3. Test temperature ranged from 1200 to $1477 \mathrm{~K}$ and the stress-rupture time from 0.1 to about $1000 \mathrm{hr}$. The error bar 
indicates a representative range of rupture time data at one stress. The 10- and 100-hr stressrupture strengths, $\sigma_{t=10}$ and $\sigma_{t=100}$, determined from the stress-rupture curves, are summarized in Table II. The difference in the $\sigma_{t}$ between the Mo-base alloy and the W-base alloy wires increased with increasing rupture time and testing temperatures. At $1200 \mathrm{~K}$, the $\sigma_{\mathrm{t}=10}(10-\mathrm{hr}$ stress-rupture strength) and the $\sigma_{\mathrm{t}=100}$ were, respectively, 1237 and $1038 \mathrm{MPa}$ for MoHfC, and 1275 and $1221 \mathrm{MPa}$ for WHfC. At $1366 \mathrm{~K}$, the $\sigma_{\mathrm{t}=100}$ of MoHfC was much lower than that of WHfC, i.e., $480 \mathrm{MPa}$ versus $950 \mathrm{MPa}$.

It is noted that the difference in the $\sigma_{t}$ between the simple MoHfC and the MoHfC $+45 \mathrm{~W}$ also increased with increasing temperature and time. At $1200 \mathrm{~K}$, the $\sigma_{\mathrm{t}=10}$ of MoHfC was comparable with that of MoHfC+45W (about $1237 \mathrm{MPa}$ ). From 1366 to $1477 \mathrm{~K}$, the 100 -hr stress-rupture strength of the MoHfC $+45 \mathrm{~W}$ wires was substantially higher than that of the MoHfC wires, whereas the 10-hr short-term strength of the $\mathrm{MoHfC}+45$ wires was slightly higher than that of MoHfC wires. This suggests that the $\mathrm{W}$ containing $\mathrm{Mo}$ alloy wires may be a candidate composite fiber reinforcement wires for the long-term and high temperature applications, and the simple MoHfC wires may be suitable for short-term and low temperature application below $1400 \mathrm{~K}$.

The relationship between the initial stress and the rupture time, $t_{R}$, is shown in Fig. 4 as a function of testing temperature for the MoHfC wires. At 1200 and $1600 \mathrm{~K}$ a unique slope existed for each temperature, and the stress-rupture strength value at $1200 \mathrm{~K}$ was clearly higher than that at $1600 \mathrm{~K}$ for all the rupture times. The slope at $1200 \mathrm{~K}$ was steeper than that at $1600 \mathrm{~K}$. From 1366 to $1477 \mathrm{~K}$, however, two slopes existed, one for rupture times above about $10 \mathrm{hr}$, and another one for the relative short-term rupture time of less than $10 \mathrm{hr}$. The two different slopes at 1366 and $1477 \mathrm{~K}$ resulted in that the long-term $\sigma_{t=100}$ of $\mathrm{MoHfC}$ wires at $1366 \mathrm{~K}$ was considerably higher than that at $1477 \mathrm{~K}, 500$ and $300 \mathrm{MPa}$, respectively. The sharp drop of the stress rupture strength for the long-term rupture time is associated with the change in the fibrous grain structures, such as grain broadening.

The relation between the initial stress and the rupture time of the MoHfC was correlated by using the conventional power-law expression [8,9]:

$$
t_{R}=A \sigma^{-p} \exp (Q / R T)
$$

where $t_{R}=$ rupture time $(\mathrm{hr}), A=$ constant, $\sigma=$ applied stress $(\mathrm{MPa}), \mathrm{p}=$ stress exponent for stress-rupture, $T=$ testing temperature $(K), R=$ gas constant $(8.314 \mathrm{~J} / \mathrm{mol} . \mathrm{K})$ and $\mathrm{Q}=$ apparent activation energy for stress-rupture $(\mathrm{kJ} / \mathrm{mol})$. The stress exponent, $\mathrm{p}$, the slope of the curves in

TABLE II.-10- AND 100-HR STRESS-RUPTURE STRENGTH OF Mo AND W BASE ALLOY WIRES

\begin{tabular}{|l|c|r|c|c|c|c|c|c|c|c|}
\hline \multirow{2}{*}{ Wire } & \multicolumn{3}{|c|}{ 10-Hr stress-rupture strength at K, } & \multicolumn{5}{c|}{ 100-Hr stress-rupture strength at K, } \\
& \multicolumn{3}{|c|}{ MPa } \\
\cline { 2 - 11 } & 1200 & 1366 & 1400 & 1477 & 1600 & 1200 & 1366 & 1400 & 1477 & 1600 \\
\hline MoHfC & 1237 & 728 & 564 & 464 & ${ }^{2} 160$ & 1038 & 480 & 350 & 310 & ${ }^{2} 91$ \\
MoHfC+25W & --- & 675 & --- & 494 & --- & --- & 574 & --- & 405 & -- \\
MoHfC+45W & 1237 & 808 & --- & 615 & ---- & 1038 & 679 & --- & 589 & --- \\
WHfC & 1275 & 1176 & -- & --- & --- & 1221 & 950 & --- & b780 & --- \\
\hline
\end{tabular}

${ }^{2}$ Extrapolated from the measured short-term data.

'From Petrasek et al.'s report. 
Fig. 4, is high, about 14 , at $1200 \mathrm{~K}$ over the entire test time range, and at 1366 and $1477 \mathrm{~K}$ for the short-term tests. A high p value at low temperatures is indicative of a high sensitivity of the rupture time with the applied stress, the observed stress value for $\sigma_{t=10}$ is almost equivalent to $\sigma_{t=100}$ at $1200 \mathrm{~K}$. The long-term stress-rupture data at $1366 \mathrm{~K}$ displayed considerable scatter, however, the data appeared to correlate best with a stress exponent of about 5 . The apparent activation energy, $Q$ for the stress versus rupture-time was determined to be about $480 \mathrm{~kJ} / \mathrm{mol}$ over the stress range of 400 to $500 \mathrm{MPa}$, for temperatures of 1366 to $1477 \mathrm{~K}$, and for the longterm rupture time data of about $10 \mathrm{hr}$ or larger. This value compares well with the steady-state creep value of $470 \mathrm{~kJ} / \mathrm{mol}$ determined for recrystallized TZM Mo alloy at 1573 to $1673 \mathrm{~K}$ [10].

\section{DISCUSSION}

\section{Strengthening by the Dispersoid Particles}

The tensile and stress-rupture properties of the $\mathrm{HfC}$ dispersed Mo alloy wires appear to have comparable strengths to the WHfC wires at about $1200 \mathrm{~K}$. However, for temperatures above $1200 \mathrm{~K}$, the Mo-base alloy wires are weaker than the W-base alloy wires. The addition of $\mathrm{W}$ as an alloying element enhances the stability of the microstructure at high temperature and yields a higher strength MoHfC base alloy.

The short-term and/or low temperature tensile and stress-rupture strength results from the fibrous grain structures and Hall-Petch type grain boundary strengthening. The fine fiber grain contains more elastically stored energy $[3,11]$, which results from the large amount of cold working employed in the wire drawing process, and contributes considerably to the wires strength. For example, the high tensile strength of the heavily drawn Mo-33Re alloy was reported to be due to the highly developed, fine scale, cell structures with a high background dislocation density [12]. For the HfC dispersoids strengthened Mo alloy, the long-term and high temperature stressrupture and tensile strengths, however, may be the combined effects of strengthening from the fine dispersoids, Orowan stress from the dispersoids, and/or the solid solution hardening from the strong and hard alloying element. The fine and closely distributed HfC dispersoids have been shown to effectively block dislocation motion and to affect the formation of the cell and wall structures [11].

Table III shows the increase in the tensile and stress-rupture strength of the hafnium carbide dispersed wires compared to the literature values of the unalloyed wires and recrystallized $W$ or Mo sheets at $1366 \mathrm{~K}$. The increase in the tensile strength of the hafnium carbide dispersed wires was about fivefold and sevenfold for the stress-rupture strength in comparison to W and Mo sheets, respectively. The increase in tensile strength due to the addition of HfC particles to Mo or $\mathrm{W}$ and the cold work was about $650 \mathrm{MPa}$, which is somewhat higher than earlier estimates: Previous work indicated about a $120 \mathrm{MPa}$ increase for the $200 \mu \mathrm{m}$ WHfC wires with a 1.55 vol\% fraction of HfC [3].

\section{Property Comparisons}

The stress-rupture data for the wires indicated that in the higher temperature range the WHfC wires have a higher strength than the MoHfC wires and that the $\mathrm{W}$ addition to the MoHfC is an effective strengthener. The density compensated specific strength values, stress/density, i.e., 
TABLE III.-THE INCREASE IN THE TENSILE AND STRESS-

RUPTURE STRENGTH OF THE HFC PARTICLE DISPERSED

MOHFC AND WHFC WIRES IN COMPARISON TO THE

UNALLOYED MOLY AND TUNGSTEN

WIRES AT $1366 \mathrm{~K}$

\begin{tabular}{|c|c|c|c|c|c|}
\hline Material & Condition & $\begin{array}{l}\text { Particle } \\
\text { size, } \\
\text { nm }\end{array}$ & $\begin{array}{l}\text { Units, } \\
\text { MPa }\end{array}$ & $\begin{array}{c}\text { 100-Hr stress- } \\
\text { rupture strength, } \\
\mathrm{MPa}\end{array}$ & $\begin{array}{l}\text { Young's } \\
\text { modulus } \\
\text { GPa }\end{array}$ \\
\hline $\begin{array}{l}\text { MoHfC } \\
\text { Mo } \\
\text { Mo }\end{array}$ & $\begin{array}{l}\text { Wire }(380 \mu \mathrm{m}) \\
\text { Wire }(380 \mu \mathrm{m}) \\
\text { Sheet } \\
\text { (recrystallized) }\end{array}$ & $\begin{array}{l}150 \\
-- \\
--\end{array}$ & $\begin{array}{r}970 \\
a_{320} \\
b_{172}\end{array}$ & $\begin{array}{l}480 \\
b_{80} \\
b_{57}\end{array}$ & $\overline{-\cdots}$ \\
\hline $\begin{array}{l}\text { WHfC } \\
\text { W } \\
\text { W }\end{array}$ & $\begin{array}{l}\text { Wire }(380 \mu \mathrm{m}) \\
\text { Wire }(380 \mu \mathrm{m}) \\
\text { Sheet } \\
\quad \text { (recrystallized }\end{array}$ & $\begin{array}{l}35 \\
-- \\
--\end{array}$ & $\begin{array}{l}1340 \\
\mathrm{a}_{6} 650 \\
\mathrm{~b}_{241}\end{array}$ & $\begin{array}{r}950 \\
a_{460} \\
b_{145}\end{array}$ & b365 \\
\hline
\end{tabular}

${ }^{a}$ Unpublished work by H.M. Yun.

bFrom reference [5].

$\mathrm{MPa} /\left(\mathrm{g} / \mathrm{cm}^{3}\right)$ or $\mathrm{m}$, are an important criteria in choosing a candidate wire for fiber composite reinforcement. Figure 5 shows the comparison of the density compensated stress-rupture strength of the MoHfC, MoHfC $+25 \mathrm{~W}, \mathrm{MoHfC}+45 \mathrm{~W}$ and WHfC wires, including the 218, ST300, and W4ReHfC [13]. It is noted that the specific rupture strength of Mo-base wires is almost equivalent to that of the WHfC wires The 100-hr specific rupture strength of the Mo-base alloy wires appeared to be lower at $1366 \mathrm{~K}$ than that of the W4ReHfC wires.

The present HfC dispersed Mo-base wires (MoHfC, $\mathrm{MoHfC}+25 \mathrm{~W}$ and $\mathrm{MoHfC}+45 \mathrm{~W}$ ) also have a higher 100-hr specific rupture strength than the lamp grade $218 \mathrm{~W}$ or the thoria dispersed ST300 wire at 1366 or $1477 \mathrm{~K}$. These results indicate that the MoHfC wire reinforced composites, such as $\mathrm{Nb}$ alloy matrix composites, may have a greater stress-rupture strength than similar composites reinforced with the 218 or ST300 W wire [1].

\section{SUMMARY}

Tensile and stress-rupture behavior of molybdenum (Mo) and tungsten (W) alloy wires, $380 \mu \mathrm{m}$ diameter, have been studied in the temperature range of 1200 to $1600 \mathrm{~K}$, and the results are summarized below:

(1) Long-term stress-rupture strength of the MoHfC wires was improved by $\mathbf{W}$ addition.

(2) The tensile strength of the MoHfC wires increased with increasing strain rates, and the strain rate dependency increased with increasing temperatures.

\section{CONCLUSION}

The hafnium carbide dispersed Mo-base alloy wires have a higher stress-rupture strength than the commercially available W-base alloy wires. The density compensated specific strengths of MoHfC wires is comparable to those of the strongest experimental W-base alloy wires. These 
Mo-base alloy wires, therefore, appear to be an attractive alternative candidate for metal matrix composite fiber reinforcements.

\section{REFERENCES}

1. D.W. Petrasek and R.H. Titran: "Creep Behavior of Tungsten/Niobium and Tungsten/Nb-1 Percent Zirconium Composites," NASA TM-100804, National Aeronautics and Space Administration, Washington, DC, 1988.

2. D.W. Petrasek: "High-Temperature Strength of Refractory-Metal Wires and Consideration for Composite Applications," NASA TN D-6881, National Aeronautics and Space Administration, Washington, DC, 1972.

3. H.M. Yun: "Tensile Behavior of Tungsten and Tungsten-Alloy Wires from 1300 to $1600 \mathrm{~K}$," "Proc. of the Symposium on Refractory Metals-State of the Art," sponsored by The Metall. Soc. of AIME, Chicago, II, Sept. 27-29, 1988, pp. 49-64.

4. D.W. Petrasek and R.A. Signorelli: "Stress-Rupture and Tensile Properties of Refractory-Metal Wires at 2000 and $2200^{\circ} \mathrm{F}$ (1093 and $1204^{\circ} \mathrm{C}$ )," NASA TN D-5139, National Aeronautics and Space Administration, Washington, DC, 1969.

5. T.E. Tietz and J.W. Wilson: "Behavior and Properties of Refractory Metals," Stanford University Press, Stanford, CA, 1965, pp. 156-205.

6. J.A. Houck: "Physical and Mechanical Properties of Commercial Molybdenum Base Alloys," Defense Metal Information Center Rept. 140, OTS PB 151099, 1960.

7. D.L. McDanels and R.A. Signorelli: "Stress-Rupture Properties of Tungsten Wire from 1200 to 2500 'F," NASA TN D-3467, National Aeronautics and Space Administration, Washington, DC, 1966.

8. R. Warren and C.H. Anderson: "Short Term Tensile Strength and Creep Behavior of Tungsten Wires up to $1100^{\circ} \mathrm{C}$," "Proc. 10th Plansee Seminar, vol. 2, H.M. Ortner, ed., Metallwerk Plansee, Austria, 1981, pp. 243-246.

9. S.L. Robinson and O.D. Sherby: "Mechanical Behavior of Polycrystalline Tungsten at Elevated Temperature," Acta Metall., 1969, vol. 17, pp. 109-125.

10. D. Agronov, E. Freund, and A. Rosen: "The Contribution of Particle Strengthening on the Creep Resistance of Molybdenum Alloys," High Temperature-High Pressure, 1986, vol. 18, pp. 151-159.

11. R. Ebeling and M.F. Ashby: Phil. Mag., 1966, vol. 13, pp. 805-834.

12. R.N. Wright, J.A. Brusso, and D.E. Mikkola: "A Study of the Various Contribution to Structural Strengthening in Mo-33Re Rolled to Large Strains," Materials Sci. and Engineer., 1988, A104, pp. 85-93. 
13. D.W. Petrasek: "High-Temperature Strength of Refractory-Metal Wires and Consideration for Composites Applications," NASA TN D-6881, National Aeronautics and Space Administration, Washington, DC, 1972.

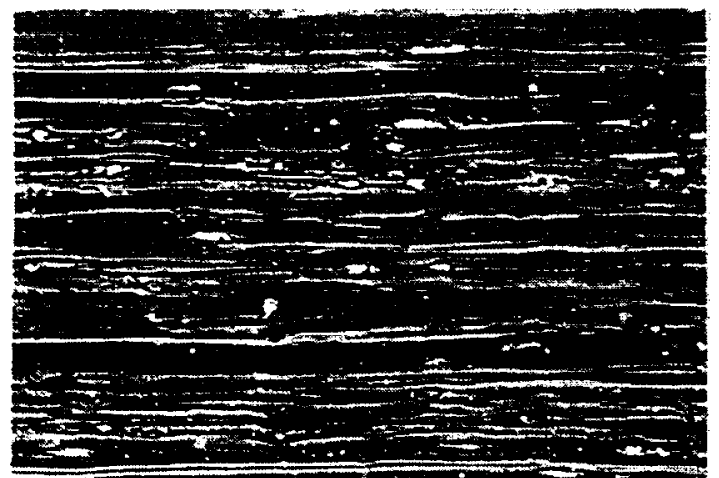

MoHfC

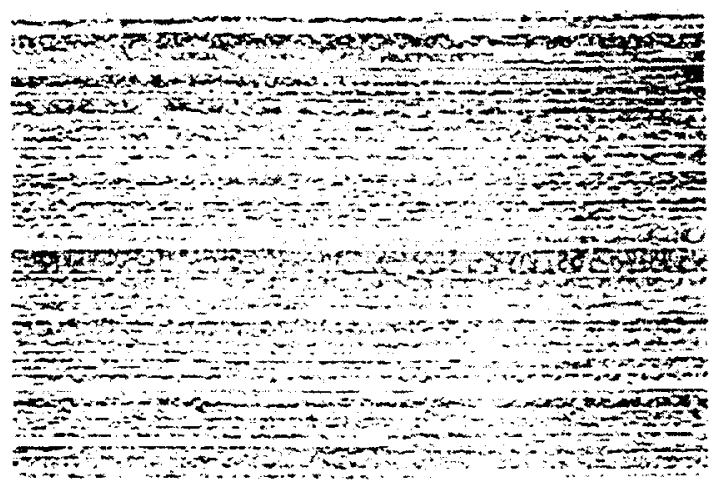

WHfC

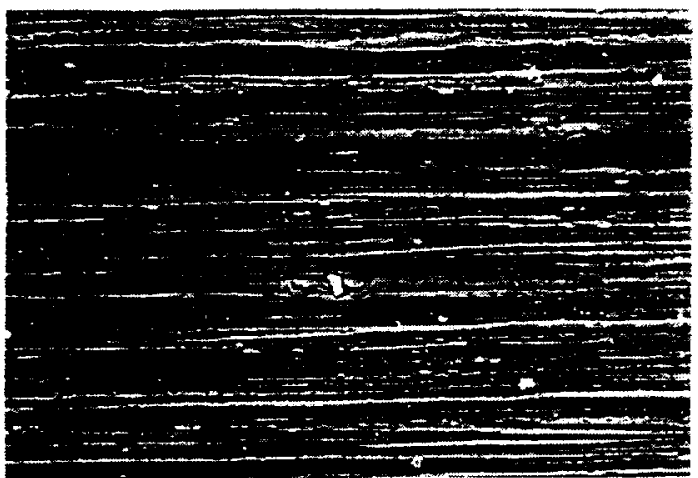

$\mathrm{MOHfC}+25 \mathrm{~W}$

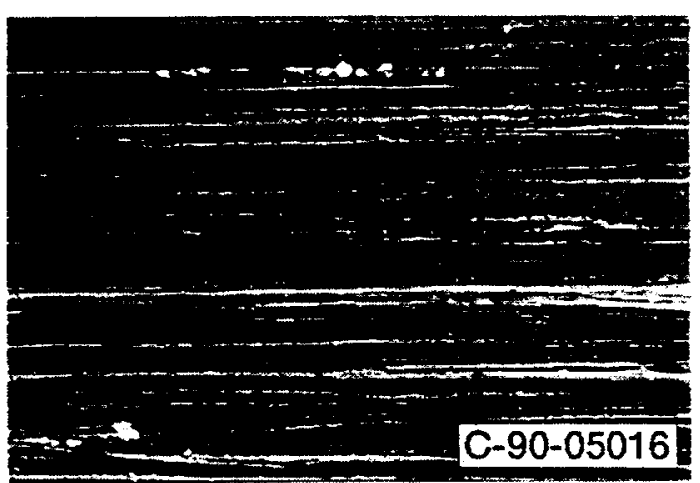

$\mathrm{MoHfC}+45 \mathrm{~W}$

Figure 1.-As-drawn microstructures (SEM secondary electron images) of Mo and $W$ base alloy wires. 


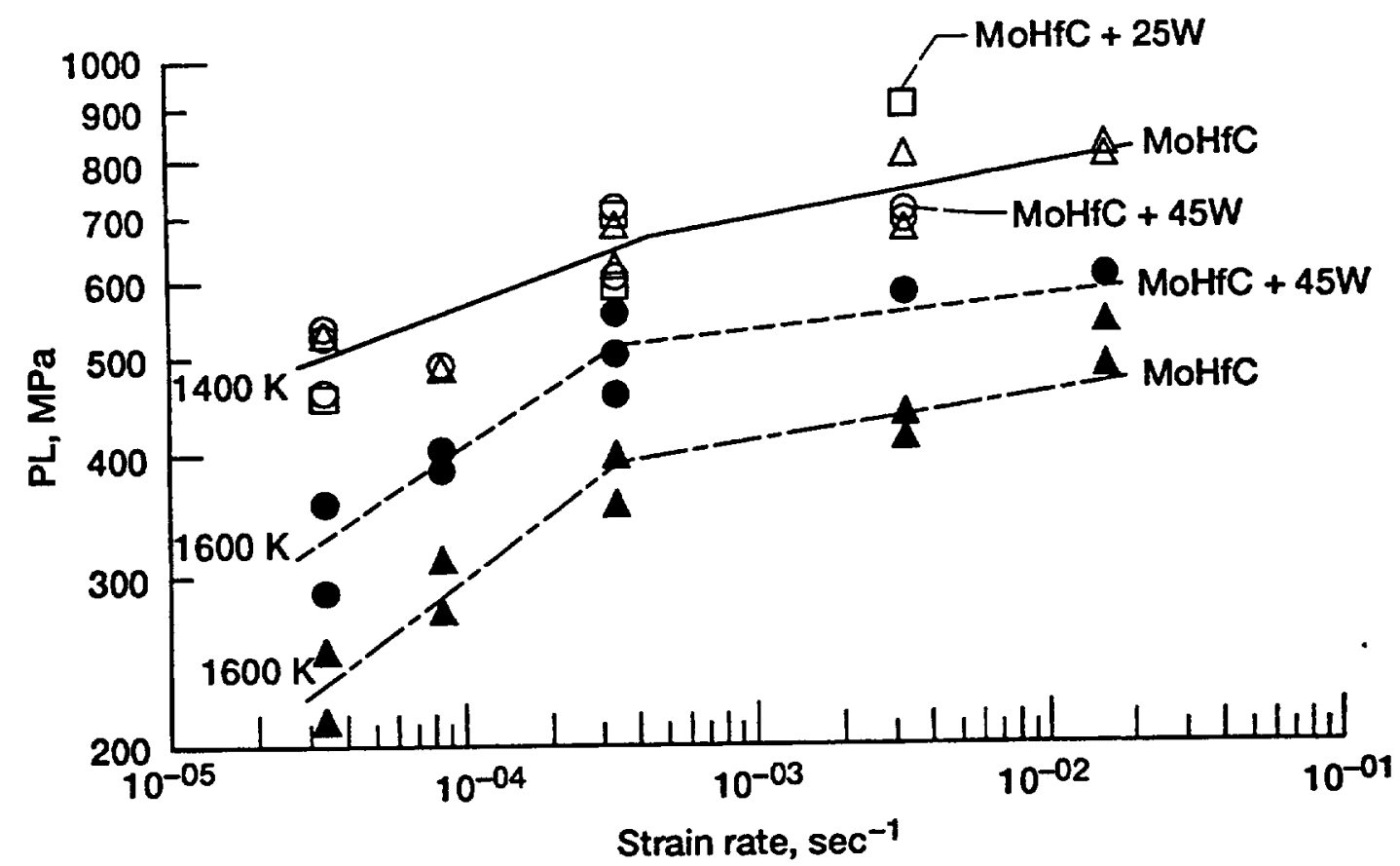

Figure 2.-Effect of the strain rate on the tensile strength of Mo-base alloy wire at 1400 and $1600 \mathrm{~K}$.

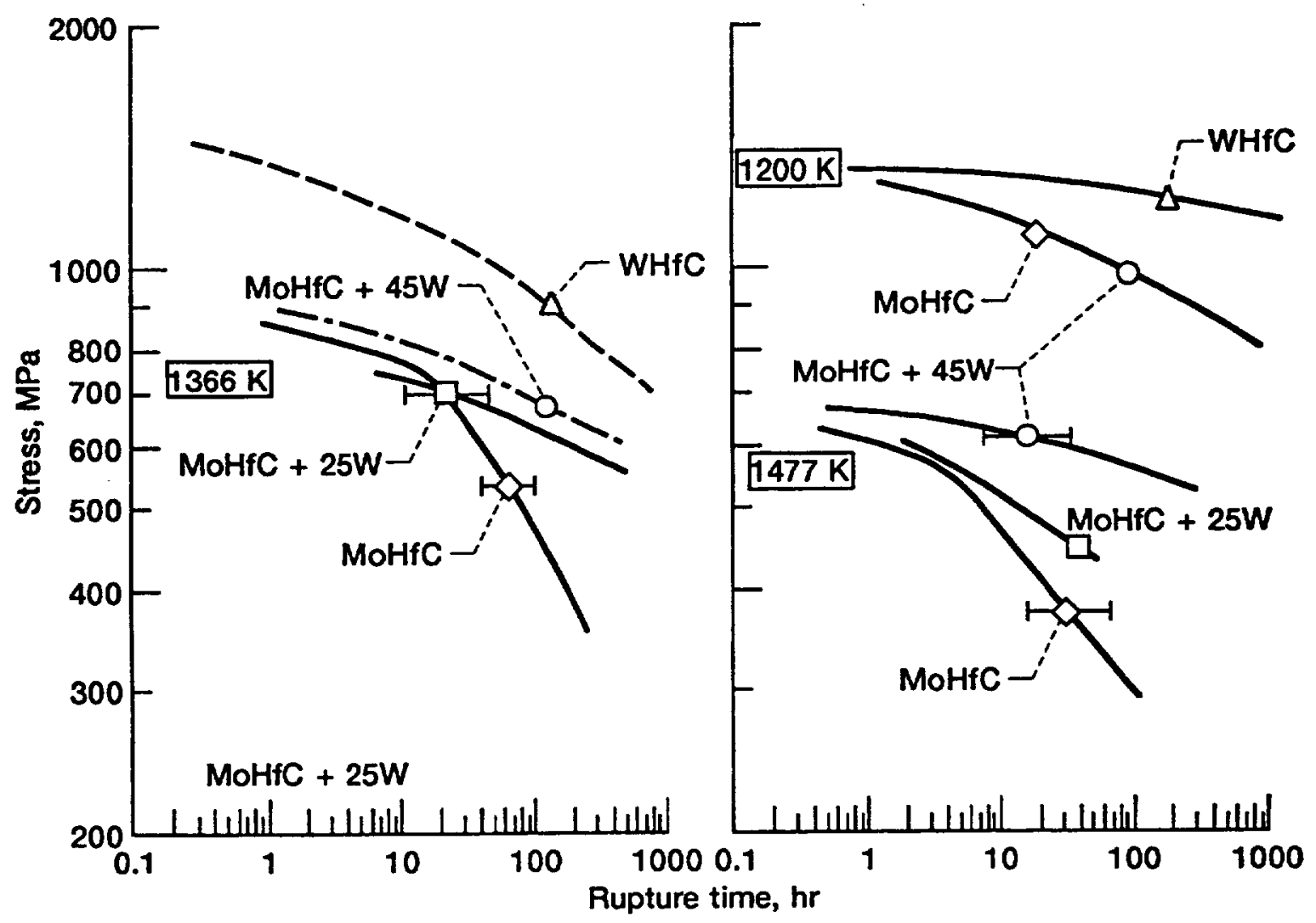

Figure 3.-Stress-rupture behavior of Mo- and W-base alloy wire at 1200,1366 and $1477 \mathrm{~K}$. 


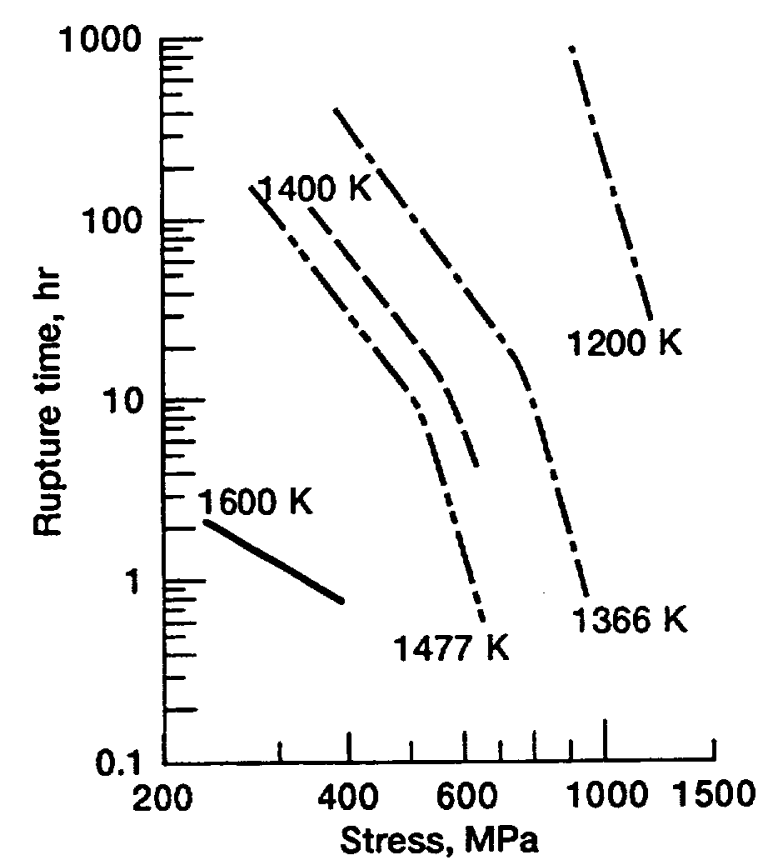

Figure 4.-Stress-rupture behavior of asdrawn MoHfC wires in the temperature range of 1200 to $1600 \mathrm{~K}$.

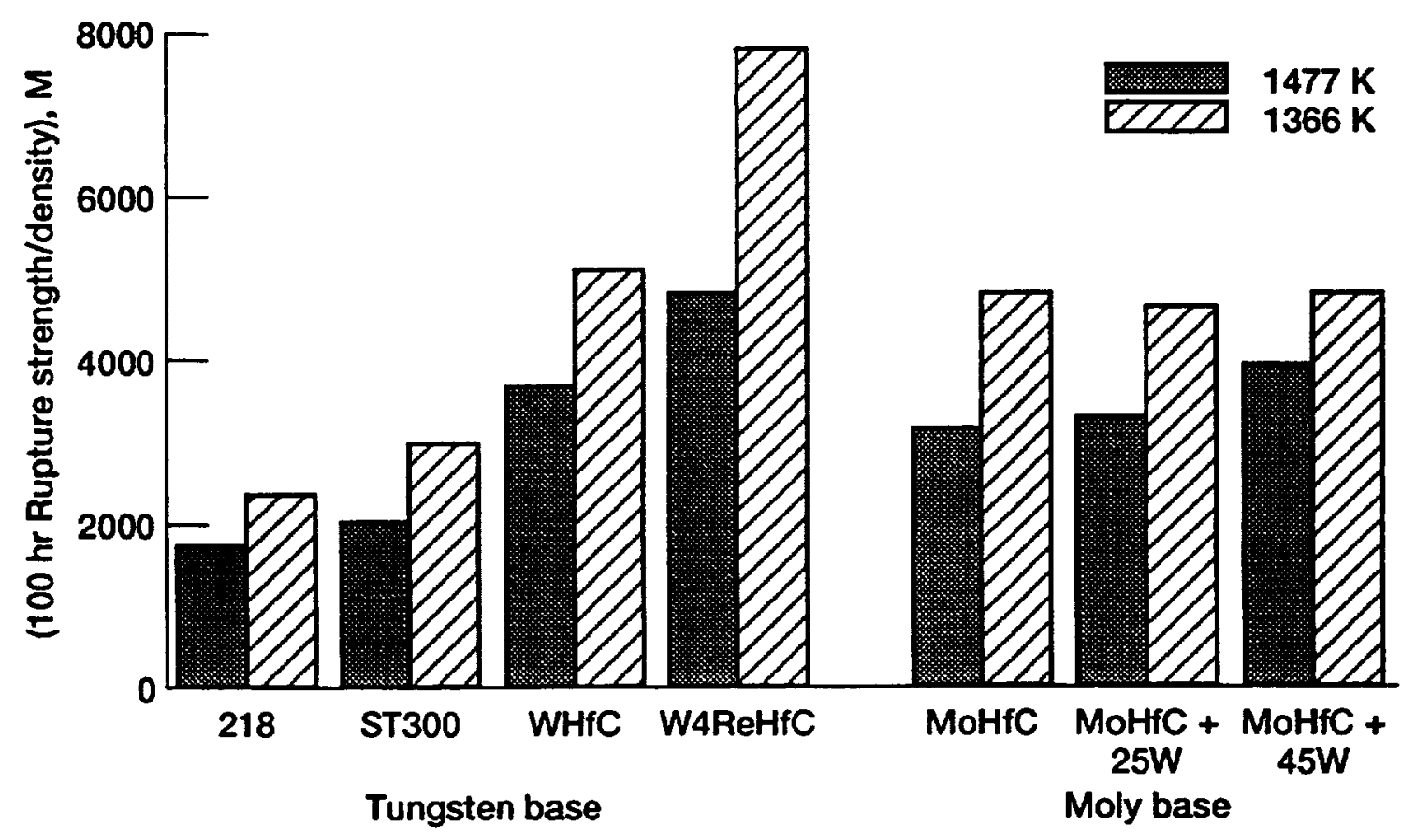

Figure 5.-Comparison of density compensated $100 \mathrm{hr}$-stress-rupture strength of candidate Mo- and W-base alloy wires for fiber reinforcements. The value of 218, ST300 and W4ReHfC wires came from the reference [4]. 
Public reporting burden for this collection of information is estimated to average 1 hour per response, including the time for reviewing instructions, searching existing data sources, gathering and maintaining the data needed, and completing and reviewing the collection of information. Send comments regarding this burden estimate or any other aspect of this collection of information, including suggestions for reducing this burden, to Washington Headquarters Services. Directorate for Intormation Operations and Reports, 1215 Jelfor

\begin{tabular}{l|l|l}
\hline 1. AGENCY USE ONLY (Leave blank) & 2. REPORT DATE & 3. REPORT TYPE AND DATES COVERED
\end{tabular}

\begin{tabular}{|c|c|c|}
\hline - AGENCY USE ONLY (Leave blank) & $\begin{array}{l}\text { 2. REPORIDAIE } \\
\text { December } 1993\end{array}$ & Technical Memorandum \\
\hline
\end{tabular}

\section{TILE AND SUBTITLE}

Tensile and Stress-Rupture Behavior of Hafnium Carbide Dispersed Molybdenum and Tungsten Base Alloy Wires

6. AUTHOR(S)

Hee Mann Yun and Robert H. Titran

\section{PERforming ORganization MAME(S) AND ADDRESS(ES)}

National Aeronautics and Space Administration

Lewis Research Center

Cleveland, Ohio 44135-3191

9. SPONSORING/MONITORING AGENCY NAME(S) AND ADDRESS(ES)

National Aeronautics and Space Administration

Washington, D.C. 20546-0001

\section{FUNDING NUMBERS}

WU-590-13-11
8. PERforinING ORganization

REPORT NUMBER

E-8128

11. SUPPLEMENTARY NOTES

Final Report. Prepared under Interagency Agreement DE-AI03-86F16310. Hee Mann Yun, Cleveland State University, Cleveland, Ohio 44115; and Robert H. Titran, NASA Lewis Research Center. Prepared for The Materials Research Society Fall Meeting, Boston, Massachusetts, December 1-5, 1993. Responsible person, Hee Mann Yun, (216) 433-6089.

12a. DISTRIBUTIONIAVAILABILTY STATEMENT

Unclassified-Unlimited

Subject Category 26 12b. DISTRIBUTION CODE

DOE Category UC-504

\section{ABSTRACT (Maximum 200 words)}

The tensile strain rate sensitivity and the stress-rupture strength of Mo-base and W-base alloy wires, $380 \mu \mathrm{m}$ in diameter, were determined over the temperature range from $1200 \mathrm{~K}$ to $1600 \mathrm{~K}$. Three molybdenum alloy wires; Mo $+1.1 \mathrm{w} / \mathrm{o}$ hafnium carbide (MoHfC), Mo $+25 \mathrm{w} / \mathrm{o} \mathrm{W}+1.1 \mathrm{w} / \mathrm{o}$ hafnium carbide $(\mathrm{MoHfC}+25 \mathrm{~W})$ and $\mathrm{Mo}+45 \mathrm{w} / \mathrm{O} \mathrm{W}+1.1 \mathrm{w} / \mathrm{o}$ hafnium carbide $(\mathrm{MoHfC}+45 \mathrm{~W})$, and a $\mathrm{W}+0.4 \mathrm{w} / \mathrm{o}$ hafnium carbide (WHfC) tungsten alloy wire were evaluated. The tensile strength of all wires studied was found to have a positive strain rate sensitivity. The strain rate dependency increased with increasing temperature and is associated with grain broadening of the initial fibrous structures. The hafnium carbide dispersed W-base and Mo-base alloys have superior tensile and stress-rupture properties than those without HfC. On a density compensated basis the $\mathrm{MoHfC}$ wires exhibit superior tensile and stress-rupture strengths to the WHfC wires up to approximately $1400 \mathrm{~K}$. Addition of tungsten in the Mo-alloy wires was found to increase the long-term stressrupture strength at temperatures above $1400 \mathrm{~K}$. Theoretical calculations indicate that the strength and ductility advantage of the $\mathrm{HfC}$ dispersed alloy wires is due to the resistance to recrystallization imparted by the dispersoid.

\section{SUBJECT TERMS}

Tensile test; Strain-rate; Stress-rupture; Recrystallization; Tungsten; Molybdenum; Hafnium carbide

\begin{tabular}{l|c}
\hline 17. SECURTY CLASSIFICATION & $\begin{array}{c}\text { 18. SECURITY CLASSIFICATION } \\
\text { OF REPORT } \\
\text { OF THIS PAGE } \\
\text { Unclassified }\end{array}$ \\
Unclassified
\end{tabular}
19. SECUATY CLASSIFICATION
OF ABSTRACT Unclassified 


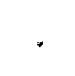

